\title{
The evaluation of different levels diets protein for growth performance of Clarias sp. fry cultured in biofloc-based system
}

\section{Evaluasi pemberian kadar protein pakan berbeda terhadap kinerja pertumbuhan benih lele Clarias sp. yang dipelihara dengan sistem bioflok}

\author{
Noviati Rohmatul Khasanah, Nur Bambang Priyo Utomo*, Mia Setiawati, Munti \\ Yuhana \\ Department of Aquaculture, Faculty of Fisheries and Marine Science, Bogor Agricultural University \\ Campus IPB Dramaga Bogor, West Java, Indonesia 16680 \\ *E-mail: nurbambang_priyoutomo@yahoo.com
}

\begin{abstract}
The study was conducted to evaluate the performance of catfish fry grown using different dietary protein levels in the biofloc-base aquaculture system. Experiments using a completely randomized design, consisted of four treatments and three replications. The treatment consisted of: protein $38 \%(\mathrm{~A}), 34 \%$ protein $(\mathrm{B}), 30 \%$ protein (C), and protein $26 \%$ (D). Catfish with initial weight of $0.83 \pm 0.01 \mathrm{~g}$ and length of $4.64 \pm 0.04 \mathrm{~cm}$ were cultured in $60 \mathrm{~L}$ tank with density of 90 fish each tank for 35 days. Inoculation of heterotrophic bacterial Staphylococcus lentus $\mathrm{L} 1 \mathrm{k}$ were performed of $10^{4} \mathrm{CFU} / \mathrm{mL}$ ratio of 15 was administrated once a day after two hours feeding in the morning. Feeding was conducted twice a day at $5 \%$ of the biomass weight. At the end of trial treatment (D) showed the highest survival rate $(88.15 \pm 5.25 \%)$, the body lenght variance coefficient $(9.58 \pm 0.51 \%)$ and protein retention $(39.87 \pm 2.77 \%)$. Treatment (B) showed the highest growth rate $(4.11 \pm 0.05 \%)$, total length $(2.39 \pm 0.08 \mathrm{~cm})$, and feed intake (318.76 \pm 4.63$)$. Treatment (A) showed the highest feed efficiency $(93.65 \pm 4.43 \%)$ while lowest lipid retention compared to others $(22.20 \pm 1.20 \%$.). Based on the results, it can be concluded that $34 \%$ protein feed (C) can replace $38 \%$ protein feed (B) catfish fry size $4-5 \mathrm{~cm}$ through biofloc-based system.
\end{abstract}

Keywords: biofloc, fry, growth, protein, Staphylococcus lentus L1k

\begin{abstract}
ABSTRAK
Penelitian bertujuan mengevaluasi kinerja pertumbuhan benih lele dengan menggunakan kadar protein pakan yang berbeda pada sistem bioflok. Percobaan dilakukan menggunakan rancangan acak lengkap, terdiri atas empat perlakuan dan tiga ulangan. Perlakuan terdiri atas protein $38 \%$ (A), protein $34 \%$ (B), protein $30 \%$ (C), dan protein $26 \%$ (D), terdiri atas empat perlakuan dan tiga ulangan. Benih lele dengan berat rata-rata $0,83 \pm 0,01$ $\mathrm{g}$ dan panjang rata-rata $4,64 \pm 0,04 \mathrm{~cm}$ dipelihara di akuarium berukuran $90 \times 50 \times 40 \mathrm{~cm}^{3}$ dengan padat tebar 90 ekor/akuarium selama 35 hari. Inokulasi bakteri heterotrof berupa Staphylococcus lentus L1k dilakukan pada setiap perlakuan kepadatan $10^{4} \mathrm{CFU} / \mathrm{mL}$. Penambahan sumber karbon berupa molase dengan C/N (Carbon/ Nitrogen) rasio 15 diberikan satu kali sehari setelah dua jam pemberian pakan di pagi hari. Pakan diberikan dua kali sehari sebanyak 5\% dari berat biomasa. Hasil penelitian menunjukkan pemberian kadar protein pakan berbeda memberikan hasil yang positif. Perlakuan (D) menunjukkan tingkat kelangsungan hidup $(88,15 \pm 5,25 \%)$, koefisien keragaman panjang $(9,58 \pm 0,51 \%)$ dan retensi protein $(39,87 \pm 2,77 \%)$ terbaik. Perlakuan (B) menunjukkan laju pertumbuhan harian $(4,11 \pm 0,05 \%)$, panjang total $(2,39 \pm 0,08 \mathrm{~cm})$, dan jumlah konsumsi pakan $(318,76 \pm 4,63)$ tertinggi. Perlakuan (A) menunjukkan efisiensi pakan $(93,65 \pm 4,43 \%)$ tertinggi namun menunjukkan retensi lemak $(22,20 \pm 1,20 \%)$ terendah. Berdasarkan hasil penelitian disimpulkan bahwa pemberian pakan dengan kadar protein $34 \%$ mempunyai performa pertumbuhan yang sama dibandingkan protein $38 \%$ pada benih ikan lele berukuran $4-5$ yang dipelihara menggunakan sistem budidaya bioflok.
\end{abstract}

Kata kunci: benih lele, protein, pertumbuhan, bioflok, Staphylococcus lentus L1k 


\section{INTRODUCTION}

Feed contributes as the largest proportion in the production cost spent in the culture of catfish Clarias sp., either in the grow-out phase or hatchery. Farmers in the hatchery generally use the feed with the high protein levels ranging between $38-40 \%$ to reach the maximum output. The price of the feed with a high protein level is relatively expensive and is not matched with the low selling price of the fish fry. Catfish is a freshwater fish that becomes one of the major consumption fish in Indonesia with the market demand that continues to increase every year. An increase in the demand causes an increase in the need for the catfish fry, but this high demand value is not matched with adequate fry stocks. Intensification in a hatchery is one of the most appropriate solutions to fulfill the demand for the fry that is continuously increasing. Intensive culture system leads to the high use of the protein-rich artificial feed, causing problems in the form of aquaculture waste (Gunadi, 2012). The aquaculture waste is derived from the accumulation of organic residues from the unconsumed feed, feces, and the low level of the fish ability to retain the protein contained in the feed, ranging between $20-25 \%$. Those can lead to the formation of ammonia that pollutes the culture mediums (Avnimelech, 2007).

Protein is one of the essential nutrients for the growth. The fish fry will grow optimally, if the energy derived from the protein used for the body maintenance has been fulfilled, so the excess energy will be used entirely for the growth (Lovell, 1988). The protein requirement for the fry stadia is still quite high, so it needs a solution to intensively overcome various problems existed in the hatchery. Biofloc technology is one of the waste treatment technologies in aquaculture that can be used as an alternative solution to overcome various issues existed in the intensification programs performed in a hatchery (De Schryver et al., 2008). The main principle in the biofloc technology is water quality management that utilizes the ability of heterotrophic bacteria to convert organic and inorganic nitrogen through the administration of a carbon source, such as molasses with a $\mathrm{C} / \mathrm{N}$ ratio of 15 , the balance of $\mathrm{C}$ and $\mathrm{N}$ is the key in the formation of a floc by heterotrophic bacteria (Ekasari, 2009), Staphylococcus lentus L1k is one of the heterotrophic bacteria that has a function as an industrial waste bioremediation agent (Sekar et al., 2012). Fidyandini et al. (2016) stated that the administration of $S$. lentus L1k could reduce the ammonia concentration in the rearing ponds and increased the survival of catfish. The addition of heterotrophic bacteria L1k with a concentration of $10^{4} \mathrm{CFU} / \mathrm{mL}$ showed the best growth rate on the catfish fry reared in biofloc-based system (Salamah et al., 2015).

Several advantages resulted in the application of biofloc-based system, including the ability to reduce ammonia (Avnimelech, 2007), the floc aggregate formed in the biofloc-based culture system can be used as natural food sources (Ekasari et al., 2010), the addition of feed nutrients in biofloc-based system is able to increase the growth and feed efficiency (Frame \& Gunarto, 2012), flocs have a high protein content (Xu et al., 2012), a reduction in the use of the protein of the feed in the biofloc-based system culture does not interfere the growth and the health status of the shrimp, so that it can be an alternative to decrease the protein level in the feed that is automatically able to reduce the production cost in the hatchery (Xu \& Pan, 2014). A decrease in the protein level contained in the diet on the freshwater fish (the catfish fry) culture through biofloc-based system has not been done, so it is necessary to conduct a study to evaluate the growth performance of the catfish fry reared in the biofloc-based system with different protein levels in the diets.

\section{MATERIALS AND METHODS}

\section{Experimental design}

This study was carried out with an experimental method through a completely randomized design (CRD) with four treatments and three replications as follows: PA: Treatment A (diet with a protein level of 38\%), PB: Treatment B (diet with a protein level of 34\%), PC: Treatment C (diet with a protein level of 30\%), PD: treatment D (diet with a protein level of $26 \%$ ).

Raw materials used in this study included fish meal, meat bone meal, soybean meal, pollard, corn oil, fish oil, premix, and Carboxy Methyl Cellulose (CMC). Those raw materials were mixed and were then molded to be pellets. Those were weighed according to the formulation, then mixed starting from the raw material that had a little proportion within the formulation to the raw material that had the highest proportion within the formulation, $30 \%$ water $(\mathrm{v} / \mathrm{w})$ was then added and was mixed until forming a dough. That dough was molded with a moulding machine at a diameter of 1-2 mm and was dried using an oven 
at a temperature of $35^{\circ} \mathrm{C}$ for 24 hours. The diet fed to the catfish fry was crushed into small granules or powders. The proximate analysis results of the experimental diet are presented in Table 1.

\section{The rearing of the experimental fish}

The experimental fish used were the catfish fry derived from a private hatchery in Bogor. The catfish fry were acclimatized for a week and were placed in the rearing containers. The average weight of the catfish fry was $0.83 \pm 0.01 \mathrm{~g}$ and the average length of the catfish fry was $4.64 \pm 0.04$ $\mathrm{cm}$. The fish were reared in 15 units of aquarium sizing $90 \times 50 \times 40 \mathrm{~cm}^{3}$ equipped with three aeration points. Each aquarium was filled with $60 \mathrm{~L}$ water. Furthermore, each aquarium was filled with 1 $\mathrm{L}$ waste water from the catfish culture to make flocs formed rapidly (Septiani et al., 2014). The fish were stocked into aquariums with a stocking density of 90 individuals/aquarium and were fed with a feeding rate of 5\% determined from the biomass twice a day. The fish were reared for 35 days, and before weighing the weight of the fish fry, the fry were fasted for 24 hours. Fifteen fish were anaesthetized, then stored in the freezer for the initial proximate analysis of the fish.

The addition of molasses as the carbon source was performed once a day at two hours after feeding in the morning. The carbon source was added to the aquarium with a $\mathrm{C} / \mathrm{N}$ ratio of 15 (De Schryver, 2008). The inoculation of heterotrophic bacteria S. lentus L1k was done on each treatment, at a dose of $0.6 \mathrm{~mL} / \mathrm{m}^{3}$ and a density of $10^{4} \mathrm{CFU} /$ $\mathrm{mL}$, every week (Salamah et al., 2015). For the sampling of biomass and the length of the catfish fry, there were $30 \mathrm{ind} /$ aquarium randomly taken from 90 individuals of catfish in each aquarium. The sampling was done every week and the fish were previously fasted for 24 hours. In addition to know the biomass, the sampling of the fish weight aimed to determine the amount of molasses added to the rearing container, with an assumption the biomass considered in equal value for a week.

At the end of the rearing period, the fish with a weight of $20 \mathrm{~g}$ was taken from each aquarium for the proximate analysis of the fish body. The floc was taken at a weight of $20 \mathrm{~g}$ from the water column in each aquarium using a plankton net for the proximate analysis to know the nutrients contained in the floc.

\section{Parameters observed}

Daily growth rate

Daily growth rate was calculated using a formula:

$$
\mathrm{SGR}=(\ln \mathrm{Wt}-\ln \mathrm{Wo}) / \mathrm{t} \times 100
$$

Note:

$\mathrm{SGR}=$ specific growth rate $(\% /$ day $)$

$\mathrm{Wt}=$ the average weight of the fish at the endof the study $(\mathrm{g})$

Wo $=$ the average weigth of the fish at the beginning of the study $\mathrm{T}_{1}(\mathrm{~g})$

$\mathrm{t}=$ rearing period

\section{Total length}

Total length of the fish body was measured using a ruler and was calculated using a formula:

$$
\mathrm{P}(\mathrm{cm})=\mathrm{Pt}-\mathrm{Po}
$$

Note:

$\mathrm{P} \quad=$ total length growth $(\mathrm{cm})$

$\mathrm{Pt}=$ the average length of the fish at the end of rearing period $(\mathrm{cm})$

Po $=$ the average length of the fish at the beginning of rearing period $(\mathrm{cm})$

Table 1 . The proximate analysis results of the diet expressed in dry weight (\%)

\begin{tabular}{lcccc}
\hline \multirow{2}{*}{ Parameters } & $\mathrm{A}(38 \%)$ & $\mathrm{B}(34 \%)$ & $\mathrm{C}(30 \%)$ & $\mathrm{D}(26 \%)$ \\
\cline { 2 - 5 } Protein (\%) & 38.01 & 34.23 & 30.19 & 26.10 \\
Fat $(\%)$ & 7.11 & 5.7 & 4.30 & 3.33 \\
Ash (\%) & 18.15 & 15.20 & 12.13 & 10.49 \\
Crude fiber (\%) & 6.53 & 8.11 & 9.33 & 11.52 \\
NFE (\%) & 30.44 & 37.34 & 44.02 & 48.52 \\
Gross energy (kcal/kg) & $3,948.57$ & $3,898.51$ & $3,827.50$ & $3,703.79$ \\
C/P ratio & 10.38 & 11.38 & 12.67 & 14.18 \\
\hline
\end{tabular}

* NFE $=$ nitrogen free extract 


\section{Length variance coefficient}

Length variance coefficient (VC), was calculated using this following formula:

$$
\mathrm{VC}=(\mathrm{s} / \mathrm{y}) \times 100
$$

Note:

$\mathrm{VC}=$ Length variance coefficient (\%)

$\mathrm{S} \quad=$ Standard deviation

y $\quad=$ Mean of the sample

\section{Feed efficiency}

Feed efficiency was calculated using the formula according to Takeuchi (1988):

$$
\mathrm{FE}=[((\mathrm{Wt}+\mathrm{Wd})-\mathrm{Wo}) / \mathrm{F}] \times 100
$$

Note:

$\mathrm{FE} \quad=$ feed efficiency $(\%)$

$\mathrm{F} \quad=$ the amount of the feed given during the rearing period $(\mathrm{g})$

$\mathrm{Wt}=$ total weight of the fish at the end of rearing period $(\mathrm{g})$

Wo = total weight of the fish at the initial of rearing period $(\mathrm{g})$

$\mathrm{Wd}=$ total weight of the dead fish $(\mathrm{g})$

\section{Protein retention}

Protein retention was calculated using a formula:

$$
\mathrm{PR}=[(\mathrm{F}-\mathrm{I}) / \mathrm{P}] \times 100
$$

Note:

$\mathrm{PR} \quad=$ protein retention $(\%)$

$\mathrm{F} \quad=$ the amount of protein in the fish body at the end of rearing period $(\mathrm{g})$

I = the amount of protein in the fish body at the initial of rearing period $(\mathrm{g})$

$\mathrm{P} \quad=$ the amount of protein in the feed consumed during the rearing period $(\mathrm{g})$

\section{Lipid retention}

Lipid retention was calculated using a formula:

Note:

$$
\mathrm{LR}(\%)=[(\mathrm{F}-\mathrm{I}) / \mathrm{P}] \times 100
$$

LR = lipid retention (\%)

$\mathrm{F}=$ the amount of lipid in the fish body at the end of rearing period $(\mathrm{g})$

I = the amount of lipid in the fish body at the initial of rearing period $(\mathrm{g})$

$\mathrm{P} \quad=$ the amount of lipid in the feed consumed during the rearing period $(\mathrm{g})$

\section{Survival}

Survival (SR), was calculated with this following formula:

$$
\mathrm{SR}=\mathrm{Nt} / \mathrm{No} \times 100
$$

Note:

$\mathrm{SR}=\operatorname{survival}(\%)$

$\mathrm{Nt}=$ the number of the alive fish at the final observation (individuals)

No $=$ the number of the alive fish at the initial observation (individuals)

\section{Proximate analysis}

The proximate analysis was conducted at the beginning and the end of the study. The proximate analysis conducted at the beginning of the study included the proximate analysis of the diet raw materials, the proximate analysis of the carbon source, the proximate analysis of the fish body, and the proximate analysis of the experimental diet, while those conducted at the end of the study were the proximate analysis of nutrients in the floc and the proximate analysis of the fish body.

\section{Floc volume}

Fifty $\mathrm{mL}$ water sample was taken from the water column, then deposited for 30 minutes in a conical tube with a volume of $50 \mathrm{~mL}$. The volume of the deposited floc was recorded and was then calculated with this formula:

Floc volume $(\mathrm{mL} / \mathrm{L})=\underline{\text { Sediment volume }} \times 1000$ Water sample volume

\section{Statistical analysis}

Data collected were analyzed by Microsoft Excel 2007. Data were then analyzed through analysis of variance (ANOVA) at a confidence level of 95\% using SPSS 17. If there were significant differences among treatments, then further analyzed through the Duncan's test.

\section{RESULTS AND DISCUSSION}

\section{Results}

Growth performance

The growth performance of the catfish fry reared for 35 days, including daily growth rate, total length, variance coefficient, feed efficiency, feed intake, protein retention, lipid retention, and survival were presented in Table 2. Treatment B showed the best daily growth rate that was not significantly different $(\mathrm{P}>0.05)$ with treatment 
A, but it was significantly different $(\mathrm{P}<0.05)$ with other treatments, the highest total length value was found on treatment $B$ that was not significantly different $(\mathrm{P}>0.05)$ with treatment $\mathrm{A}$ and $C$, treatment $A$ and $C$ were not significantly different $(P>0.05)$ with treatment $D$, variance coefficient values were not significantly different $(\mathrm{P}>0.05)$ among one treatment and others, the best feed efficiency was found on treatment A that was not significantly different $(\mathrm{P}>0.05)$ with treatment $\mathrm{B}$, but it was significantly different $(\mathrm{P}<0.05)$ with other treatments, feed intake values were not significantly different $(\mathrm{P}>0.05)$ among one treatment and others, the highest protein retention was found on treatment $\mathrm{C}$ that was not significantly different $(\mathrm{P}>0.05)$ with other treatments, the highest lipid retention was found on treatment $\mathrm{D}$ that was significantly different $(\mathrm{P}<0.05)$ with other treatments, survivals were not significantly different $(\mathrm{P}>0.05)$ among one treatment and others.

\section{Floc nutrients}

Nutrients contained in the floc formed in the rearing mediums were analyzed at the end of the study and the samples were taken from the water column. The nutrients observed were protein, lipid, ash, crude fiber, and nitrogen free extract (NFE). Table 3 showed that the floc formed had high protein content values observed in all treatments. The results of statistical analysis demonstrated that there was no significant difference $(\mathrm{P}>0.05)$ among treatments on protein, lipid, ash, crude fiber and NFE.

\section{Floc volume}

Data in Figure 1 showed that the floc volume increased every week. Drastic increase were found on week 1 to week 2 and week 2 to week 3 , then starting to be stable on week 3 to week 5 on all treatments. The floc volume fluctuation was presented in Figure 1.

\section{Discussion}

Feeding with different protein levels in the diet demonstrated positive responses on the growth performance of the catfish fry. A reduction of the protein level in the diet at a value of $8 \%$ (from $38 \%$ to be $30 \%$ ) (Table 2) did not interfere the growth performance of the catfish fry. There was no significant difference $(\mathrm{P}>0.05)$ on the survival of the catfish fry among treatments. This was in line with the study by Xu and Pan (2014) that reported treatments with different protein levels in the feed applied on the shrimp juvenile reared in biofloc-based system showed equally good results among treatments. The same result was revealed by Ballester et al. (2010) who reported that feeding with different protein levels in the diet did not show any significantly different result on the survival of Farfantepenaeus paulensis among treatments. Salamah et al. (2015) stated that the administration of heterothropic bacteria L1k through the different feed in biofloc-based environment resulted the survival of the catfish fry up to $92.67 \%$. The high survival of the catfish fry was caused by the present of the floc aggregate formed in containers that minimized canabalism (Table 2). That floc aggregate containes poly- $\beta$ -

Table 2. The growth performance of the catfish fry during a 35-day-rearing

\begin{tabular}{lcccc}
\hline & \multicolumn{4}{c}{ Protein levels in the diet } \\
\cline { 2 - 5 } Parameters & $\mathrm{A}(38 \%)$ & $\mathrm{B}(34 \%)$ & $\mathrm{C}(30 \%)$ & $\mathrm{D}(26 \%)$ \\
\hline DGR (\%/day) & $4.05 \pm 0.07 \mathrm{~b}$ & $4.11 \pm 0.05 \mathrm{~b}$ & $3.89 \pm 0.08 \mathrm{a}$ & $3.61 \pm 0.10 \mathrm{a}$ \\
Total length $(\mathrm{cm})$ & $2.35 \pm 0.07 \mathrm{ab}$ & $2.39 \pm 0.07 \mathrm{~b}$ & $2.32 \pm 0.03 \mathrm{ab}$ & $2.24 \pm 0.08 \mathrm{a}$ \\
Variance coefficient $(\%)$ & $10.66 \pm 0.73 \mathrm{a}$ & $9.70 \pm 0.66 \mathrm{a}$ & $9.58 \pm 0.51 \mathrm{a}$ & $10.08 \pm 0.73 \mathrm{a}$ \\
Feed efficiency $(\%)^{*}$ & $93.65 \pm 4.43 \mathrm{~b}$ & $91.32 \pm 3.61 \mathrm{~b}$ & $82.55 \pm 1.85 \mathrm{a}$ & $80.50 \pm 2.69 \mathrm{a}$ \\
Feed intake* & $312.61 \pm 1.32 \mathrm{a}$ & $318.76 \pm 4.63 \mathrm{a}$ & $304.40 \pm 3.67 \mathrm{a}$ & $279.17 \pm 16.28 \mathrm{a}$ \\
Protein retention $(\%)^{*}$ & $34.58 \pm 1.62 \mathrm{a}$ & $36.98 \pm 2.40 \mathrm{a}$ & $39.87 \pm 2.77 \mathrm{a}$ & $37.19 \pm 1.07 \mathrm{a}$ \\
Fat retention $(\%)^{*}$ & $22.20 \pm 1.20 \mathrm{a}$ & $22.80 \pm 4.56 \mathrm{a}$ & $31.12 \pm 3.79 \mathrm{~b}$ & $40.64 \pm 2.09 \mathrm{c}$ \\
SR $(\%)^{*}$ & $79.26 \pm 3.39 \mathrm{a}$ & $80.37 \pm 2.32 \mathrm{a}$ & $88.15 \pm 5.25 \mathrm{a}$ & $82.59 \pm 1.70 \mathrm{a}$ \\
\hline
\end{tabular}

Note: *the calculation of feed intake was based on the amount of pellets consumed by the fish and did not include the amount of the eaten floc, DGR = daily growth rate, SR = survival, different letters in the same row indicate significant differences $(\mathrm{P}<0.05)$. The values shown were means and standard deviations. 
Table 3. The composition of floc nutrients expressed in dry weight $(\%)$ in rearing mediums of the catfish fry treated with different protein levels in the diet during a 35-day-rearing

\begin{tabular}{lcccc}
\hline \multirow{2}{*}{ Composition } & \multicolumn{4}{c}{ Protein levels in the diet } \\
\cline { 2 - 5 } & $\mathrm{A}(38 \%)$ & $\mathrm{B}(34 \%)$ & $\mathrm{C}(30 \%)$ & $\mathrm{D}(26 \%)$ \\
\hline Protein (\%) & $33.06 \pm 1.26 \mathrm{a}$ & $35.31 \pm 2.70 \mathrm{a}$ & $32.80 \pm 1.80 \mathrm{a}$ & $30.84 \pm 1.63 \mathrm{a}$ \\
Lipid (\%) & $4.43 \pm 0.70 \mathrm{a}$ & $4.48 \pm 0.51 \mathrm{a}$ & $4.59 \pm 0.60 \mathrm{a}$ & $4.35 \pm 0.15 \mathrm{a}$ \\
Ash (\%) & $19.16 \pm 4.67 \mathrm{a}$ & $16.49 \pm 1.44 \mathrm{a}$ & $20.45 \pm 1.9 \mathrm{a}$ & $20.32 \pm 3.80 \mathrm{a}$ \\
Crude fiber (\%) & $15.51 \pm 3.71 \mathrm{a}$ & $13.17 \pm 1.17 \mathrm{a}$ & $18.41 \pm 7.14 \mathrm{a}$ & $16.97 \pm 7.84 \mathrm{a}$ \\
NFE (\%)* & $28.03 \pm 1.42 \mathrm{a}$ & $29.21 \pm 1.96 \mathrm{a}$ & $23.73 \pm 8.59 \mathrm{a}$ & $27.50 \pm 9.98 \mathrm{a}$ \\
Gross energy (kcal $/ \mathrm{kg})$ & $3,338.11 \pm 167.41 \mathrm{a}$ & $3,512.57 \pm 135.57 \mathrm{a}$ & $3,162.29 \pm 365.53 \mathrm{a}$ & $3,189.33 \pm 451.01 \mathrm{a}$ \\
\hline
\end{tabular}

$* \mathrm{NFE}=$ nitrogen free extract.

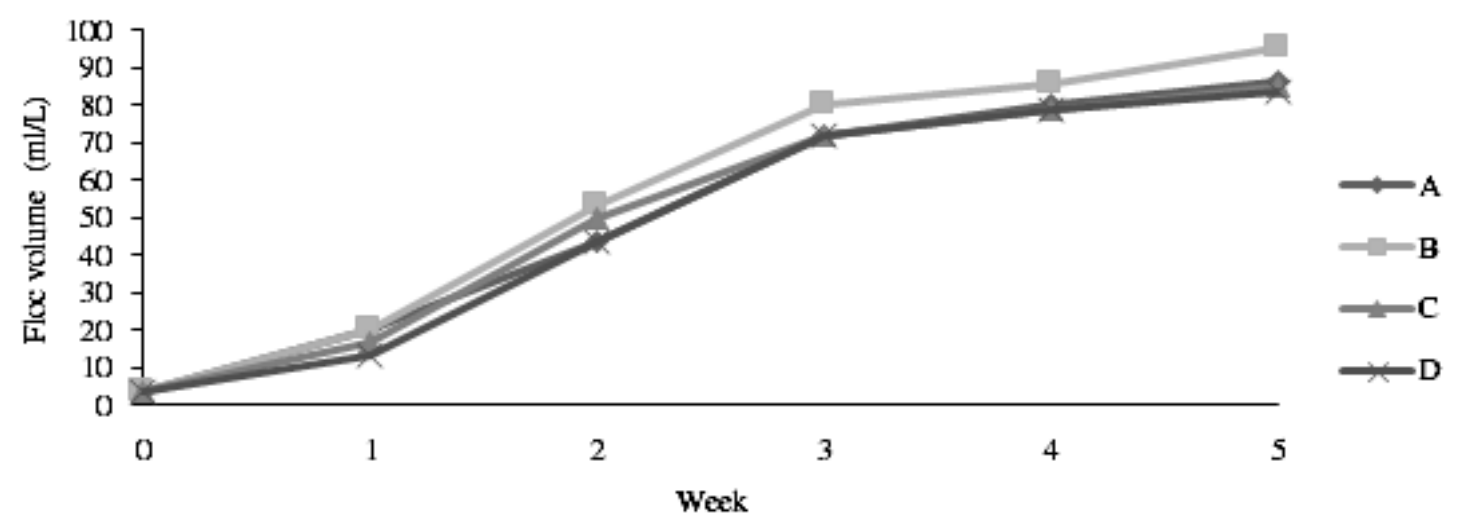

Figure 1. The floc volume formed in the rearing medium of the catfish fry during a 35-day-rearing.

hydroxybutirate (PHB) ranging from 0.9 to $1.6 \%$ that is quite enough to fulfill the PHB requirement of the fish at a value of $1 \%$ (De Schryver et al., 2009). The PHB is a product produced by various microorganisms as an energy deposit (Defroird et al., 2007). The present of PHB can boost the immune system of the fish that prevents the entrance of patogens to the body. The formation of the floc aggregate becomes the key in the success of biofloc-based culture system (Ekasari, 2009).

The smaller the variance coefficient value, the better the uniformity. The result of the statistical analysis indicated that the values of the length variance coefficient were not significantly different $(\mathrm{P}>0.05)$ among treatments. It proved that the catfish fry got a chance to prey the same amount of the food, so there was no competition for a food space. According to Lovell (1989), if the size of the catfish fry is not uniform, it will cause a chance to get the food becoming different, the fry which has a big size has the opportunity to dominate the food than the smaller fry due to differences in the body size. The existence of biofloc as the feed provider in situ is proven to help in avoiding the food space competition or the opportunity to dominate the food. That biofloc contained in the rearing medium had a positive effect on the growth of the catfish fry.

A reduction of protein level in the diet at a value of $8 \%$ (from $38 \%$ to be $30 \%$ ) (Table 2) did not affect the growth performance of the catfish fry. This was in line with the study by Ballester et al. (2010) that stated a reduction of protein level in the feed at a value of $10 \%$ on F. paulensis reared in a biofloc-based environment did not influence the growth performance. It is caused by the application of biofloc-based system in the rearing medium giving an additional nutrition apart from the feed (Crab, 2010). This was proven with the high protein content contained in the floc detected in the proximate analysis of the floc nutrients expressed in dry weight that ranged between 30.84 $\pm 1.63-35.31 \pm 2.70$ (Table 4).

The application of biofloc technology can increase feed utilization efficiency (De Schryver et al., 2008; Ballester et al., 2010; Xu and Pan, 2014). The higher the feed efficiency, the lower the Feed Conversion Ratio (FCR). The use of the bacteria L1k as the supporting agent in growing 
heterothropic bacteria in a biofloc environment gave a significant effect on feed conversion ratio (Salamah etal., 2015). Feed efficiency on treatment A was not significantly different $(P>0.05)$ with treatment $\mathrm{B}$. The highest the feed efficiency, the more efficient the feed is utilized by the body, so that the diet with a protein level of $38 \%$ had the same quality with the diet with a protein level of $34 \%$. The high value of feed efficiency was suspected caused by the floc aggregate in rearing mediums adding nutrients into rearing mediums. This was supported with the statement by Ekasari et al. (2010) who stated that biofloc could be used as an additional nutrition in the aquafeed, and it could be demonstrated in the protein content contained in the floc according to the analysis of the floc nutrients (Table 3 ) that showed almost the same results.

Protein retention values were not significantly different $(\mathrm{P}>0.05)$ among treatments, so that it could be interpreted that the abilities of the fish to retain protein were same in all treatments. This was proven by feed intake values in all treatments that were not statistically significantly different $(\mathrm{P}>0.05)$ (Table 2). The highest lipid retention was found on the treatment with a protein level of $26 \%$, because in the diet with a protein level of $26 \%$ contained the highest carbohydrate level and the lowest protein level (Table 1). This was in accordance with the opinion by Ali and Jauncey (2005) who stated that a factor causing lipid in the body increasing was the accumulation of lipid in the liver that was caused by the feed with a low protein level and excess energy from carbohydrate contained in the feed. It was similar with the growth rate, the highest protein content was also shown by treatment $B$ on the proximate analysis of the floc nutrients (Table 3).

The proximate analysis of the floc nutrients (Table 3) demonstrated an insignificantly different result $(\mathrm{P}>0.05)$ on all treatments. This was caused by the administration of an organic carbon source in the form of molasses having the same ratio that was $15: 1$. The formation of the floc aggregate becomes the key in the success of biofloc-based culture system (Ekasari, 2009). One of floculation indicators in the biofloc rearing medium can be measured by the floc volume. The results of this study showed that the floc volume increased every week. The treatments with different protein levels resulted different floc volumes. The floc volumes at the end of the study in all treatments ranged between 83.3-95.33 $\mathrm{mL} / \mathrm{L}$. The highest floc volume was demonstrated by treatment $\mathrm{B}$ that was aligned with the result of the floc nutrients expressed in dry weight that demonstrated the highest value in treatment B (Table 3), so it could be stated that the high floc content related to the growth performance, showed that the best value demonstrated by treatment B (Table 2). This was in accordance with the opinion by Bakar et al. (2015) who stated that the administration of a carbon source with a $\mathrm{C} / \mathrm{N}$ ratio of 15 in the culture of the catfish could form the floc with a volume of $92.5 \mathrm{~mL} / \mathrm{L}$. The maximum biofloc thickness in the catfish pond is $150 \mathrm{~mL} / \mathrm{L}$ or $15 \%$ of the water volume, if it exceeds that value, the fish appetite will decrease and the fish will not be agile and nimble (Suprapto \& Samtasir, 2013). The floc thickness can be controlled by replacing the water in the medium with the new water, or by fasting the fish with an objective to make the fish consuming flocs contained in the water column in the rearing container.

\section{CONCLUSION}

The conclusion of this study was the protein level of $34 \%$ in the diet could replace the protein level of $38 \%$ applied on the catfish fry reared in biofloc-based culture system.

\section{REFERENCES}

Ali MZ, Jauncey K. 2005. Approaches to optimizing dietary protein to energy ratio for african catfish Clarias gariepinus (Burchell, 1822). Aquaculture Nutrition 11: 95-101.

Avnimelech Y. 2007. Feeding with microbial flocs by tilapia in minimal discharge biofloc technology ponds. Journal of Aquaculture 246: 140-147.

Bakar NSA, Nasir NM, Lananan F, Hamid SHA, Lam SS, Jusoh A. 2015. Optimation of c/n ratios for nutrient removal in aquaculture system culturing African catfish, Clarias gariepineus utilizing bioflocs technology. International Biodeteration dan Biodegradation 102: 100106.

Ballester ELC, Abreu PC, Cavalli RO, Emerenciano M, Abreu L, Wasielesky, W. 2010. Effect of practical diet with different protein levels on the performance of Farfantepenaeus paulensis juvenils nursed in a zero exchange suspended microbial floc intensive system. Journal of Aquaculture nutrition 16: 16-172.

Crab R, Defoirdt T, Bossier P, Verstraete W. 2012. 
Biofloc tecknology in aquaculture: beneficial effects and future challenges. Journal of Aquaculture 356-357: 351-356.

Defoirdt T, Halet D, Vervaeren $\mathrm{H}$, Boon N, Van de Wiele T, Sorgeloos P, Bossier P, Verstraete W. 2007. The bacterial storage compound of poly-b-hydrobutyrate protects Artemia fransiseana from pathogenic Vibrio campbellii. Environmental Microbiology 9: 445-452.

De Schryver P, Crab R, Defroit T, Boon N, Verstraete W. 2008. The basic of bio-flocs technology: the added value for aquaculture. Journal of Aquaculture 277: 125-137.

De Schryver P, Verstraete W. 2009. Nitrogen removal from aquaculture pond water by heterotrophic nitrogen assimilation in labscale sequencing batch reaktors. Bioresource Technology 100: 1.162-1.167.

Ekasari J. 2009. Bioflocs Technology: Theory and Application in Intensive Aquaculture System. Jurnal Akuakultur Indonesia 8: 117-126.

Ekasari J, Crab R, Vertrace W. 2010. Primary nutritional content of bio-flocs cultured with different organic carbon sources and salinity. Journal Hayati Biosciences 17: 125-130.

Fidyandini HP, Yuhana M, Lusiastuti AM. 2016. Addition of multispecies probiotics in the culture medium of african catfish to prevent the motile Aeromonads septicemia disease. Jurnal Veteriner 17: 440-448.

Lovell RT. 1988. Nutrition and feeding of fish. New York: Van Nostrand Reinhold.

Rangka NA, Gunarto. 2012. Pengaruh penumbuhan bioflok pada budidaya udang vaname pola intensif di tambak. Jurnal Ilmiah Perikanan dan Kelautan 4: 141-149.

Salamah, Utomo N. B. Y, Yuhana M, Widanarni. 2015. Growth performance of catfish, Clarias gariepinus Burchel 1822, cultured in bioflocbased system with addition of the heterotrophic bacteria cells. Jurnal Iktiologi Indonesia 15: 155-164.

Sekar S, Surianarayanan M, Perinkulam RD, Bhuvanesh KS, Phani K, Asit BM. 2012. The metabolic advantage of choline lactate in growth media: an experimental analysis with Staphylococcus lentus. Applied Biochemistry and Biotechnology 169: 380-392.

Septiani N, Maharani HW, Supono. 2014. Pemanfaatan bioflok dari limbah budidaya lele dumbo Clarias gariepinus sebagai pakan nila Oreochromis niloticus. Jurnal Rekayasa dan Teknologi Budidaya Perairan 2: 268-272.

Suprapto NS, Samtasir LS. 2013. Biofloc-165 Rahasia Sukses Teknologi Bioflok. Depok (ID): Agro 165.

Xu XJ, Pan LQ. 2014. Evaluation of dietary protein level on selected parameters of immune and antioxidant systems, and growth performance of juvenile Litopenaeus vannamei reared in zero-water exchange biofloc-based culture tanks. Journal of Aquaculture 426-427: 181188.

Xu XJ, Qing Pan I, Zhao HD, Huang J. 2012. Preliminary investigation into the contribution of bioflocs on protein nutrion of Litopenous vannamei fed with different dietary protein levels in zero-water exchange cullture tanks. Journal of Aquaculture 350-353: 147-153. 